\title{
Melnikov-Pechersky: Romancer of Provincial and Old Believer Life
}

The nineteenth-century Russian writer Melnikov-Pechersky is not well known in the West. Yet this contemporary of Dostoevsky and Tolstoy is a major literary figure who produced a series of fascinating sketches, stories, and tales about Russian provincial life as well as two epic-length novels concerned with Old Believers, In the Forests ( $V$ lesakh) and On the Hills ( $N a$ gorakh). How does one account for the relative obscurity of so important a writer outside his native land? First of all, very few translations of his works (no English ones whatsoever) have appeared in the West. ${ }^{1}$ Thus little biographical and critical material on Pavel Ivanovich Melnikov, who signed all his mature fiction "Andrei Pechersky," is available in languages other than Russian. Second, in the USSR, as in prerevolutionary Russia, both general and scholarly assessments of Melnikov are frequently clouded by extraliterary considerations. ${ }^{2}$ In other words, the reception traditionally accorded him has been ambiguous, or at best lukewarm.

This brief study is intended to dramatize the need for English translations of Melnikov's stories and novels and to suggest a new critical approach to the problem of placing his prose with its curious shape and content in the proper literary context.

Melnikov's oeuvre-an early travel story, ten or so short works, the two "epic" novels-is closely connected with the events of his life. In this respect he is like the better-known writer Nikolai Leskov (who, incidentally, con-

1. In the Forests was translated into French and German in the nineteenth century and only recently retranslated. On the Hills has only been translated within the past twenty years.

2. As a government official, Melnikov devoted many years to persecuting the very religious dissenters he ennobled in the two novels. This volte-face toward Old Believers has sparked controversy among Russian literary specialists for years, causing many to view Melnikov's writing unfavorably. Such is the case in the following studies: A. I. Bogdanovich, "Polnoe sobranie sochinenii P. I. Mel'nikova," Gody pereloma: 1893-1906 (St. Petersburg, 1908), pp. 261-72. I. S. Ezhov, "Predislovie," in P. I. Mel'nikovPechersky, $V$ lesakh, 2 vols. (Moscow, 1955), 1:3-10. N. A. Ianchuk, "P. I. Mel'nikov (Andrei Pecherskii)," Istoriia russkoi literatury XIX veka, 5 vols̀. (Moscow, 1908-10), 4:194-207. A. I. Skabichevsky, Istoriia noveishei russkoi literatury: 1848-1892 gg., 3rd ed. (St. Petersburg, 1897), pp. 218-23. S. A. Vengerov, "Pavel Ivanovich Mel'nikov," Entsiklopedicheskii slovar', vol. 37 (St. Petersburg, 1896), pp. 46-49. G. S. Vinogradov, "Fol'klornye istochniki romana Mel'nikova-Pecherskogo $V$ lesakh" in P. I. Mel'nikovPechersky, $V$ lesakh, 2 vols. (Moscow and Leningrad, 1936), 1:viii-lxvii. 
sidered Melnikov his literary mentor). Melnikov's first literary work, Travel Notes on a Journey from Tambov Province to Siberia (Dorozhnye zapiski na puti iz Tambovskoi gubernii $v$ Sibir'), emerged as a result of his "exile" assignment in Perm as a gimnasium teacher. Most of the short works and, most notably, the two novels stem directly from the writer's experiences as an official of the Ministry of Internal Affairs on assignment in Nizhny Novgorod Province. Without some biographical information, therefore, it is hard to appreciate the distinctive features of Melnikov's fiction.

Melnikov produced prose works intermittently from the late 1830 s until his death in 1883. Born in 1819 in Nizhny Novgorod (now Gorky) into a family of petty gentry, and educated at the local gimnasium and Kazan University, Melnikov began but was unable to pursue a career as a philologist. In 1838 he was appointed to a teaching post in Perm, and that year the first installments of the Travel Notes appeared in Notes of the Fatherland (Otechestvennyia zapiski), and continued to appear in this journal on a regular basis for four years. Large and sprawling, this first work more than anything else is a compendium of the writer's many diverse intellectual and artistic interests. In it Melnikov presents the physiology of an isolated area of Russia. His approach is that of an anthropologist-an approach presaging the direction and content of much of his later fiction in which attention is focused on the economic situation, history, institutions, and ethnography of people in out-of-the-way locations. For Melnikov, the beginning writer, Travel Notes was a sort of laboratory for literary experiments in which basic questions of style, narrational stance, even subject matter could be raised. An invaluable source of information, ideas, and preferences, it provides material of the sort available for other writers in notebooks, manuscripts, and diaries.

Melnikov found himself in Perm in 1838 because of an indiscreet act, unfortunately not documented, committed during the previous year at Kazan University. In place of anticipated travel abroad, the aspirant philologist received a voyage at state expense to a province described by him as a "Siberia." In the eleven-installment Travel Notes, Perm Province is treated as a "foreign" country. The work is clearly an expression of Melnikov's frustrated desire to roam new and different lands. Its narrator is a discerning traveler from another, distant part of Russia whose view of the province is reminiscent of the naive Persian travelers' view of France in Montesquieu's Lettres persanes.

For his first literary work Melnikov chose a form both popular and flexible. The travelsstory writer need not worry about such matters as length, form, characterization, and plot. Melnikov could display his erudition, experiment with prose, conduct polemics with other writers and scholars, even criticize society, and not feel he was going beyond its limits. Travel literature 
traditionally has been broad in scope, ranging from Homer's Odyssey, Sterne's Sentimental Journey, and Gogol's Dead Souls to quasi-belletristic reminiscences and diaries of actual travelers. ${ }^{3}$

Two aspects of the Travel Notes merit attention. One is its exoticism, real and invented. Semischolarly glimpses of the culture of local non-Russian peoples and bits and pieces of area folklore are complemented in the work by an artificially created illusion of exoticism. Perm Province and the city of Perm and its society are transformed into special "exotic" entities, becoming new worlds within Russia's borders. There is no need to travel abroad to experience exotic cultures and scenery. Nor, Melnikov insists, can one gain the proper perspective of one's native social milieu only from travel in foreign lands. Perm plays an important satiric role in the Travel Notes; it becomes a microcosm of nineteenth-century Russia. The other noteworthy aspect of the Travel Notes is the image of the narrator as competent scholar and wise critic. Melnikov's "Traveler" constantly displays a superior knowledge of ancient and modern cultures, historical events, and languages. Fond of mentioning scholarly books and sources, he accomplishes intellectual feats in the course of his travels which sometimes dazzle those present. A social critic as well, Melnikov's Traveler views Permian society with great irony and scorn. The narrator's image, finally, is that of a writer who engages in polemics, chats about his craft, and continually tries his hand at descriptive prose. In this first work, then, Melnikov seeks his own idiom by testing various literary styles.

Rewarded for his strong interest in area history and folklore and for his skill as a writer, Melnikov was in 1845 appointed editor of the "unofficial" part of the Nizhny Novgorod provincial newspaper, the section which appeared two or three times a week and contained news and items of local interest. Melnikov emphasized the intellectual aspect of the newspaper during his five years as editor, contributing a large number of first-rate articles to it himself and soliciting others from well-known scholars and writers. In 1847, assigned to the Nizhny Novgorod provincial governor as a special investigator, Melnikov began a series of inspections and raids on Old Believer institutions in the area which resulted in the arrest or forced conversion to Orthodoxy of many Old Believers and the closing and dismantling of Old Believer chapels and monasteries (skity). For these acts he was later ostracized from Russian literary circles.

Melnikov's first widely acclaimed story, The Krasilnikovs (Krasil'nikovy), appeared in M. P. Pogodin's Muscovite (Moskvitianin) in 1852, the same

3. For a concise study of the genre with emphasis on its role in Russian literature see T. A. Roboli, "Literatura puteshestvii," in B. M. Eikhenbaum and Iu. N. Tynianov, eds., Russkaia proza: Sbornik statei (Leningrad, 1926), pp. 42-73. 
year Melnikov was ordered by the minister of internal affairs to conduct a thorough investigation of Old Believer sectarianism in Nizhny Novgorod Province. The assignment occupied him more than two years, and the Report on the Present State of the Schism in Nizhny Novgorod Province (Otchet o souremennom sostoianii raskola $v$ Nizhegorodskoi gubernii) drawn up as a result is remarkable both for its comprehensiveness and the severe measures it recommends for curbing "Schismatic" activities. Written in highly polished official language, the Report condemns Old Believers on moral and political grounds, but also, more surprisingly, chastises the local Orthodox clergy for laxity and accuses provincial officials of corrupt practices in dealing with Schismatics. This monumental work is still used as a basic reference by scholars interested in the Russian Schism. ${ }^{4}$

The Report turned out to be a double-edged sword. Given fewer and far less important assignments than ever before, Melnikov began writing and had by 1859 published seven additional stories. In 1859 he founded and edited a semiofficial St. Petersburg daily, Russian Diary (Russkii dnernik), but it was not successful, and six months after its inception he accepted an invitation to join the editorial board of the conservative Northern Bee (Severnaia pchela).

Altogether Melnikov-Pechersky (he began using the pseudonym at this time) published twelve short works in the decade 1852-62. Seven deserve special attention: The Krasilnikovs (1852), Grandpa Polikarp (Dedushka Polikarp, 1857), Poiarkov (1857), Olden Times (Starye gody, 1857), Grandma's Yarns (Babushkiny rosskazni, 1858), At the Posting Station (Na stantsii, 1859), and Grisha (1860). ${ }^{5}$ Only the first, The Krasilnikovs, has a clearly defined plot. It is the story of a prosperous tanner's family tragedy. Kornila Egorych Krasilnikov, the main protagonist, is a crafty businessman who has accumulated immense wealth. Yet his entire existence is governed by a strict religious ethic. A great admirer of Western commercial efficiency, he has allowed his favorite son and heir, Dmitrii ("Mitka"), to receive a university education and to travel extensively abroad. He is incapable, however, of permitting the son to marry a neighboring family's German governess. When he finds out that Mitka has been secretly married to her for some time, he loses

4. In Robert O. Crummey's recent study of the Vyg Old Believer community, The Old Belicvers and the World of Antichrist (Madison, 1970), for example, Melnikov's Report is cited frequently.

5. Melnikov's other short works are either derivative-A Godforsaken Place (Medvezhii ugol, 1857), which is imitative of Turgenev; The Permanent Assessor (Nepremennyi, 1857) and The Naneday Pie (Imeninnyi pirog, 1858), which are reminiscent of Gogol—or, like At Makar'c (U Makar'ia, 1859), In Chudovo (V Chudove, 1862), and the later vignette, $A$ Bencfactress (Blagodetel'nitsa, 1863), semifictional in nature. One additional work, Pcople from Across the Uzola (Zauzol'tsy, 1859), is actually a highly condensed early version of the first novel, In the Forests, and is important as a "prenovel" rather than a separate short story. 
all sense of reason and beats the girl. Not long after that she dies and Mitka goes mad. He now works as a mill-hand in his father's tannery, kept in check by a brutish younger brother. Kornila refuses to admit that he himself has caused the tragedy. Instead he blames Mitka's education for what has happened. He seeks comfort in this explanation. But like the excessive and pretentious grandeur of the front half of his provincial dwelling, it is little more than a deceptive façade.

The success of the Travel Notes doubtless prompted Melnikov to give The Krasilnikows the subtitle "From Travel Notes" ("Iz dorozhnykh zapisok"), for the story organization barely justifies the designation. ${ }^{6}$ The narrator, Andrei Pechersky (same as Melnikov's pseudonym), here a government official gathering statistics in an unspecified province, visits Krasilnikov to obtain permission to survey the old man's tannery. Pechersky stylistically assimilates himself to the world described. Over vodka punch he gradually draws Kornila out. The tale acquires an "organic" conversational impetus of its own. It seems to tell itself as much as being "told" by Melnikov's narrator.

The most important clue to the story's meaning is the title, which connotes family or clan. Significantly, some critics have referred to the work mistakenly as "Semeistvo Krasil'nikovy" ("The Krasilnikov Family"). Semeistvo, literally "family-hood," is a concept vital to the story's ideological frame of reference. If Mitka had married almost any "Orthodox" woman, no conflict would have resulted. The German woman's curse is her "heretical" faith, something which would pollute the family blood. Also, Kornila insists that his university-educated son remain a tanner. Old, traditional family valuesreligion, kind, trade-cause the Krasilnikov tragedy.

The Krasilnikovs is a pilot work. Kornila Egorych is the first of four memorable self-willed male protagonists in the writer's oeuvre, followed by Prince Zaborovsky in Olden Times, Chapurin in In the Forests, and Smolokurov in On the Hills. Mitka's logical descendants are the idealized Russian businessmen combining the virtues of an old-fashioned upbringing with Western entrepreneurism, such as Kolyshkin in In the Forests and Merkulov and Vedeneev in On the Hills. The provincial setting and the Schismatic outlook and values are used successfully again and again. In terms of genre, The Krasilnikovs, with its element of melodrama, stylized language and characterization, and carefully planned narrational scheme, cannot be considered a realistic story. It is rather a type of romance, a tale dealing with exotic lore and with the inner consciousness of a freakish personality. ${ }^{7}$ As in Melnikov's

6. Melnikov even attracted attention abroad thanks to the Travel Notes, large portions of which were published in the Stuttgart journal Das Ausland ("Reisenskizzen aus dem Gouvernment Perm," 1840, nos. 150-53).

7. According to Lowrey Nelson, Jr., these are the two defining characteristics of that 
two later romances, Grandma's Yarns and Olden Times, verisimilitude, continuity of narration, moral and social questions, the concerns of the nineteenthcentury Realists, are at best given marginal attention.

Generically, Melnikov's other short works are for the most part sketches, that is, "objective" and therefore plotless depictions of a "typical" aspect or aspects of life written in the tradition begun in Russia in the 1840s by Vladimir Dal and D. V. Grigorovich. In each, Melnikov employs the distinctive skaz technique or the use of "inside" storytellers, thereby skirting, if not avoiding altogether, the problem of realistic description. Grandpa Polikarp and At the Posting Station are exposé sketches indicting by ironic implication bureaucratic corruption, and are constructed around an identical story frame: "Pechersky," now a "neutral" outsider, elicits the thoughts of unrefined peasants during a delay at a posting station. The first of these, "Grandpa" Polikarp, is sitting in the sun on the earth mound (zavalinka) that surrounds his hut, weaving bast sandals. His rambling discussion centers on two vital aspects of the local peasants' existence: the kulizhki, or patches of woodland burned and cleared for pasturage and tilling, and difficult dealings with the district forester. The second peasant, Maksimych, is a starosta or village group leader. He admires the consistency and exactitude of a new district police supervisor, who, it turns out, administers the law "strictly" to his own advantage. Grandpa Polikarp's and Starosta Maksimych's "inadvertent" revelations of official abuses, of no small impact at the time the sketches were published, have lost much of their significance. What continues to make the two short works striking is their narrational fabric. Polikarp's and Maksimych's chatter, which is characterized by many archaic and colloquial forms, conveys the flavor of a particular era and region. The exotic style of these two sketches can only be appreciated by consulting Dal's dictionary.

In the longer sketch, Poiarkov, an entirely new and important facet of Russian life, the Old Believer byt or way of life, is introduced to artistic literature. Poiarkov, now a pilgrim living out his days wandering from one holy place to another, was once a minor provincial official. Given a ride by Pechersky, he reminisces about his service experiences, especially those involving Old Believers. While telling entertaining stories and anecdotes about romps with Old Believer novices and profitable deals with Old Believer abbesses, Poiarkov affords us many glimpses of Schismatic monastic life. ${ }^{8}$

well-known type of romance, the Gothic novel. See "Night Thoughts on the Gothic Novel," Yale Review, 52 (Winter 1963): 253.

8. The freshness of subject matter of both The Krasilnikovs and Poiarkov elicited the immediate acclaim of progressive critics. I. I. Panaev, a minor writer better known as coeditor with Nekrasov of Sovremennik, praised the earlier story. See "Zametki i razmyshleniia novogo poeta po povodu russkoi zhurnalistiki," Sovremennik, 33, no. 5 (1852): 125. And Poiarkov received a brief but highly laudatory review, again in 
Closely resembling Poiarkov in this respect and forming with it a subject "prelude" to Melnikov's later novels is Grisha, the story of a young Schismatic's search for faith, in which much valuable "incidental" material on religious sectarians is presented for the first time. Stylistically and thematically tied to In the Forests and On the Hills, the story of Grisha is the proving grounds where Melnikov tested what was to become his characteristic novelistic style. No longer does he employ the impartial observer Andrei Pechersky. Instead, the story is narrated in "authentic" language, great pains being taken to convey not only all the intricacies of each character's speech but all the intricacy of the byt and people described as well.

Grisha is thematically related to the novels through its emphasis on tradition, family solidarity, and potentially disruptive forces within the Schismatic ethic. Orphaned at an early age and adopted by a prosperous Old Believer family, Grisha earns his keep looking after the wandering pilgrims who are given food and shelter by the family matriarch Evpraksiia Mikhailovna. The more pilgrims Grisha meets, the more his own faith is intensified and delimited. Pride in his own piety increases commensurably with the frequency of his love-making bouts with the earthy local wench Dunia. Finally Grisha submits himself to the will of the sleazy starets (elder) Ardalion, a man as powerhungry as he is narrow-minded. Grisha carries out Ardalion's command to destroy the family's wealth, that force of Antichrist which Ardalion calls the "teeth of Hell," since it makes possible Evpraksiia Mikhailovna's general, and therefore suspicious, Christian altruism.

Melnikov's novellas, Grandma's Yarns and Olden Times, are more problematic. Both are presented as recollections of eighteenth-century Russian life: the first deals with the reminiscences of an aged upper-class woman, and the second with the "memories" of an old groom on a provincial estate. The two works meet the definition of romance: they are prose narratives more imaginative than verisimilar, with settings and action quite remote from everyday reality." Grandma's Yarns is a romance-chronicle which recreates a bygone era. Olden Times is a "Gothic" romance.

Grandma's Yarns is narrated in a most unusual manner. Grandma's tales, which make up nine-tenths of the romance, are in the form of a monologue "recorded" years later by a great-great grandson, Andrei Pechersky. In this way Melnikov revitalizes a supposedly authentic past. The technique again is skaz, that distinctive narrative method whereby the speech forms of a particular narrator are employed to enhance the style of the surrounding text and to characterize the narrator himself. Grandma says she was born in 1736 . Her

Sovremennik, from the young radical Chernyshevsky. See N. G. Chernyshevsky, Polnoe sobranic sochinenii, 16 vols. (Moscow, 1939-53), 4:735-36.

9. The definition is based on the one in the New English Dictionary. 
memories of nineteenth-century happenings are weak, but the last forty years or so of the preceding century she recalls with remarkable clarity. Her yarns are sprinkled with French words and phrases, Russian calques of French terms, and, in a number of places, French syntax. In her old lady's mental confusion she frequently meanders, providing important background information about eighteenth-century high society mores.

Grandma's memories center on two strong personalities, one a petty tyrant, the other an enlightened young noblewoman. Reflecting the attitudes of her era, Grandma herself stands in awe of the first, a despicable individual named Sergei Mikhailovich Churilin, and censures the second, Nastenka Borovkova, whose boldness, compassion, and steadfastness she cannot help but present sympathetically. A sexual motif gives the work unity. Churilin's strength is built on erotic involvements with those around him. Nastenka Borovkova's fervent campaigns for social justice, which turn out to be a matter of virginal intransigence, are all quickly abandoned once she marries.

Olden Times is Melnikov's most elaborate short work, and its complex narration and bizarre content have baffled scholars and critics for more than a century. Possessing a narrational scheme with no less than six voices, as well as a villainous hero, a bewitched portrait, persecuted females, crumbling ruins, and the theme of incest, the work is a fine Gothic romance.

Andrei Pechersky sets the stage for Olden Times, and then meets, talks, but, more important, listens to a police supervisor in a small Volga river port who recalls tales of the old estate groom, Prokofich, about the notorious eighteenth-century prince Aleksei Iurich Zaborovsky. Prokofich's tales, along with those of other local old-timers, are recorded in the 1852 notebooks of a one-time Zaborovsky estate manager, Valiagin, and the main body of the romance begins some ten pages into the text with Pechersky's "accidental" discovery of these notebooks. By imposing a narrational complexity of this sort, Melnikov blurs point of view. The world described is further isolated, the "Gothic" or out-of-the-ordinary atmosphere further enhanced because the reader can never be entirely certain who is telling the story-Prokofich and his unnamed confreres, Valiagin, or Pechersky.

Pechersky gives Olden Times a definite context. Reacting sentimentally to the now-declining grandeur of the Zaborovsky estate and nearby monastery, he places everything he sees in historical perspective. Groping his way along dark overgrown paths on the estate's grounds, he comes across broken statues and a brick pavilion in ruins. Two portraits in the palace gallery attract his attention, that of Prince Aleksei Iurich, revealing all the cruel and evil strength of his character, and the picture of Princess Varvara, the prince's daughter-inlaw, whose telltale eyes cannot be seen because the face, mysteriously, has been smeared with blacking. 
The story's most important narrator is the old groom Prokofich. He introduces to the romance two essential ingredients of Gothic fiction-an outof-the-ordinary atmosphere and a villain-hero or "Gothic" protagonist. The Zabor'e world is out of the ordinary because it is isolated in time as well as space. Its eighteenth-century mode of life is unknown or at least unfamiliar to most readers. Prokofich becomes a "medium" for a strange and lost age. $\mathrm{He}$ recalls the time of Aleksei Iurich as a patriarchal figure, like Grandma Pechersky-the sole surviving member of a generation.

Much stronger here than in any of Melnikov's other fiction, sex in Olden Times is elemental. The opening of the Zabor'e trade fair and the prince's nameday celebration, two gala events which give the work a great deal of pageantry, both culminate in orgies. The romance's plot revolves around the prince's crime of incest, a basic theme of the Gothic novel. ${ }^{10}$ Princess Varvara, the wife of Boris, Zaborovsky's only legitimate child, is the victim. A member of the petty gentry, she, like Emily St. Aubert, heroine of Ann Radcliffe's Mysteries of Udolpho, is very beautiful and has a sense of self-dignity. Not long after Varvara's arrival at Zabor'e, Boris is called away unexpectedly to war. Left behind on the isolated estate, she is raped by the old prince and locked up in the Rose Pavilion to die, and an elaborate scheme is devised to make her disappearance seem plausible. Later, Zaborovsky, half-crazed, is reproached by Varvara's portrait and stricken by paralysis. His delirium is ended temporarily by a bleeding; he then orders the picture smeared with blacking and expires. "And what didn't happen here in the Olden Times," the police supervisor tells Pechersky. "You've perhaps read Mrs. Radcliffe's Mysteries of Udolpho. Old-time landowners in our district say that Mrs. Radcliffe might have drawn those 'mysteries' from Zabor'e."11

In the late 1850 s a radical shift occurred in Melnikov's attitude toward Old Believers. His former hostility changed to a definite benevolence. In the brief Memorandum on the Russian Schism (1857) and in a series of lengthy, semischolarly articles entitled Letters About the Schism (1862), Melnikov cautiously expresses general admiration for most Old Believers, publicizes their cause, defends both their way of life and their worship, and recommends that an official policy of tolerance be adopted toward most religious dissenters. No sound hypothesis has been advanced on why Melnikov's opinion of the Old Believers changed so unexpectedly and so completely, and unfortunately the lack of information about his life and thinking at this time makes it impossible to speculate. All that is known about these years is that Melnikov continued to fulfill small official assignments and that on numerous occasions he tried to

10. Cf. Eino Railo, The Haunted Castle (London, 1927), pp. 270-81.

11. P. I. Mel'nikov-Pechersky, Sobranie sochinenii, 6 vols. (Moscow, 1963), 1:68. 
persuade reform-minded officials of Alexander II's government to grant Old Believers full civil rights.

In 1866, upset by political events in St. Petersburg, especially by the daring attempt on Alexander II's life, out of favor in official and literary circles because of his reputation as a merciless persecutor of Old Believers, and attracted by the offer of a salaried position on the editorial board of $M . N$. Katkov's Moscow News (Moskovskiia vedomosti), Melnikov moved to the old Russian capital with unconcealed pleasure. The advantageous financial arrangement with Katkov was short-lived, however, and, having all but ended his career in the service of the Ministry of Internal Affairs by leaving Petersburg, Melnikov was soon forced to turn to writing as a source of income. Having published White Doves (Belye goluby, 1869), another series of articles examining Old Believers and other Russian religious sectarians, he contributed for six years regular installments of his first novel, In the Forests, to the prominent monthly, The Russian Messenger (Russkii vestnik). Chapters of the second long novel, On the Hills, appeared in the same journal from 1875 to 1881 , the year Melnikov suffered the first of a series of heart attacks which eventually resulted in his death on February 1, 1883.

In the Forests and On the Hills are without question Melnikov's most significant contribution to Russian literature. Popular with generations of Russian readers, they have a large body of critical literature surrounding them. ${ }^{12}$ The two works are immense, ${ }^{13}$ intricate in plot, and structurally complex. Since there are excellent synopses of the plots of both novels, ${ }^{14}$ attention here is focused primarily on the important matter of proper critical approach.

In the Forests and On the Hills share four basic characteristics. Foremost is "setting," the byt of Trans-Volga merchants and religious sectarians, the description of a social, economic, and ethical structure quite unlike that found in the works of other nineteenth-century Russian writers. Another distinctive aspect of the novels is their cast of characters, whose personalities are both convincing and memorable. A third characteristic of $I n$ the Forests and $O n$ the Hills is their distinctive language and style. Melnikov includes a great deal of folklore, real and invented, in the novels. He also meticulously formulates the speech of his characters and, more important, that of his narrator to conform as exactly as possible to the time, byt, and other circumstances of

12. There have been six separate editions of In the Forests $(1875,1880,1928,1936$, $1955,1958)$ and four of On the Hills $(1881,1901,1956,1958)$ in addition to the original publication of both novels in Russkii vestuik and to their appearance as part of the three editions of Melnikov's collected works (1897-98, 1901, 1963).

13. In the relatively compact 1963 edition of Melnikov's collected works, In the Forests occupies 1,191 pages, On the Hills 1,159.

14. See Orest Miller's Russkie pisateli posle Gogolia, 4th ed. (St. Petersburg, 1906), pp. 63-130. 
the two works. Thus both dialogue and narrative are at times archaic, at times regional, and at other times poetic. ${ }^{15}$ The fourth distinguishing mark of In the Forests and $O n$ the Hills is their underlying philosophy or "message." This is the broad and relatively simple truth that man is tossed about willy-nilly by fate-that is, by both benign and detrimental forces beyond his control or comprehension-and that he manages to deal with such forces as best he can.

Critical assessments of In the Forests and On the Hills fall into two general categories: (1) those based on the premise that the novels constitute a grand "epic" dilogy of Trans-Volga Schismatic life, and (2) those which treat the novels as two separate entities of unequal importance. The controversy over which of these two approaches is more appropriate began before publication of $O n$ the Hills was completed, and continues to the present day. ${ }^{16}$ The controversy stems ostensibly from Melnikov's own statement on the question, but actually has to do with the interrelation of the two elaborate plots and the relative unevenness of the novels as literary works of art.

In a speech given at a meeting of the Society of Lovers of Russian Literature in 1875 Melnikov spoke of $O n$ the Hills as a sequel to In the Forests. ${ }^{17}$ Notwithstanding this, In the Forests is vastly superior artistically to On the Hills. Melnikov was never able to refine and polish On the Hills as he did In the Forests. He wrote a sizable portion of the second novel while physically incapacitated, and dictated the final installments from his deathbed. ${ }^{18}$ In terms of plot, the two novels are closely related in one sense and not in another.

15. The Soviet scholar D. A. Markov has studied the use of language in In the Forests and has compiled and published an invaluable dictionary to the novel based on his findings. See D. A. Markov, "Osobennosti leksiki romana P. I. Mel'nikova-Pecherskogo $V$ lesakh," Uchenye zapiski Moskovskogo pedagogicheskogo instituta im. N. K. Krupskoi, 102 (1961) : 3-623.

16. See, for example, reviews of $O n$ the Hills which appeared in Severnyi vestnik, 1877 , no. 49, and Otechestvennyia sapiski, 257 , no. 4 (1881): 204-9, as well as V. G. Avseenko's analysis of the two novels, "Opiat' o narodnosti i o kul'turnykh tipakh," Russkii z'stuik, 122 (1876) : 362-87. For recent works see M. P. Eremin's "P. I. Mel'nikov (Andrei Pecherskii): Kritiko-biograficheskii ocherk," in P. I. Mel'nikov-Pechersky, Sobranie sochincuii (1963 ed.), 6:377-418, and F. M. Levin, "Epopeia P. I. Mel'nikova (Andreia Pecherskogo)," in P. I. Mel'nikov-Pechersky, Na gorakh (Moscow, 1956), $1: 3-28$.

17. [P. I. Mel'nikov], "Vstupitel'noe slovo k chteniiu nachala romana $\mathrm{Na}$ gorakh v Obshchestve Liubitelei Russkoi Slovesnosti" (Moscow ?, 1875), MS, Pushkinskii Dom (IRLI), fond 95, op. 1, no. 4.

18. P. S. Usov, "Etnograf-belletrist," Istoricheskii vestnik, 18 (1884): 589-90. Some of the proofs of On the Hills are in the Pushkinskii Dom (IRLI) manuscript collection (fond 95, op. 1, no. 5). It is evident from them that Melnikov was fond of making a large number of small, last-minute stylistic changes. My thanks to Kamsar Nersesovich Grigorian, assistant director, for aiding me in obtaining this and other Melnikov materiais in Pushkinskii Dom. 
The adventures of the main protagonist of In the Forests, the tysiachnik or "wealthy man" Patap Maksimych Chapurin, come to an end on the last pages of On the Hills. Bogach or "rich man" Marko Danilych Smolokurov and his God-seeking daughter, Dunia, the two principal characters of On the Hills, never appear in In the Forests. Even though the plot of In the Forests continues in On the Hills, the first novel is highly successful by itself.

In the Forests contains extensive, detailed descriptions of the life of the Chapurin family, with its patriarchal, Old Russian values, of Trans-Volga serf-merchants' various commercial enterprises, and of Old Believer institutions and activities. There are many unforgettable scenes-Nastia's funeral, Chapurin's night on the road with the wolves, the time of the forest fire, for example. Told in a prose style rich in regional and archaic vocabulary, expressions, and syntax, it incorporates Schismatic terminology, proverbs, adages, and most of the Old Believer myths, as well as spiritual and secular songs. All this is synthesized in such a way as to make the novel an organic whole, a true masterpiece. On the Hills, on the other hand, displays definite weaknesses. From an ideological point of view the novel is tendentious, painfully didactic, a preachment. A foil to the straightforward Chapurin, bogach Smolokurov amasses wealth by hook or by crook to leave his beloved daughter Dunia. Dunia, driven by a quite different urge (to find spiritual goodness in people), takes refuge in avowedly antimaterialistic surroundings-first in a Khlyst assembly or korabl', and later in the Russian Orthodox Church. This final resolution of her quest seems even more artificial, because it occurs simultaneously with the final triumph of moral forces in the Trans-Volga commercial world, of the book's pale but undeniably positive heroes or businessmen-of-the-future- the virtuous, honest, educated, Westernized, tolerant, Old Believer-nurtured merchants Vedeneev and Merkulov. Quite different from In the Forests, in which the medium-byt, characters, language, style-is actually the "message" (to use Marshall McLuhan's terminology), in On the Hills "message" takes precedence over all else; style, vitality, and even continuity break down as the work rather tediously crawls to a close.

The term "epic" crops up frequently in critical discussions of In the Forests and $O n$ the Hills. The novels have been called "An Odyssey of the Great Russian Schism," "prose epics" (bytovye romany) portraying a portion of the Russian populace "heroic" in nature, and works depicting Trans-Volga life "in its entirety." Besides subject and setting, the epic nature of In the

19. V. G. Avseenko, "Khudozhestvennoe izuchenie raskola," Russkii vestnik, 109 (1874) : 377. Vinogradov, "Fol'klornye istochniki," p. viii, and L. Iaroslavtseva, "Roman P. I. Mel'nikova (Andreia Pecherskogo) $V$ lesakh" (candidate's diss., Potemkin Institute in Moscow, 1948), pp. 378-80. L. M. Lotman, "Mel'nikov-Pecherskii," Istoriia russkoi literatury, 10 vols. (Moscow and Leningrad, 1941-56), vol. 9, pt. 2, p. 210. 
Forests and $O n$ the Hills is defined in terms of stylistic devices, characterization, pace, and structure. Critical appraisals of epic characteristics range from rather hazy statements about epic clarity, color, retardation, stance, distance, breadth, repetition, and so forth, to specific analyses of style. ${ }^{20}$ The latter studies emphasize that Melnikov provides major and minor figures with stereotyped attributes, frequently taken from Russian folk epics or byliny rather than the individualized, more "realistic" psychological and physical characteristics, and even thoughts and manners of expression, usually found in nineteenth-century Russian Realistic fiction. Many of the novels' hundreds of characters have, for example, "black" or "light blue eyes," "flashing glances," "crimson lips," "high breasts," "curls," and "light brown plaits." Many of them think as well as speak in the set formulae of folk phraseology, frequently in proverbs and adages. Flenushka is usually referred to as "sprightly Flenushka," Parasha Chapurin is forever "sleepy Parasha," Aleksei Lokhmatov is "comely Aleksei," and Vasilii Borisych's constant utterance of surprise is "Oh, temptation!"

Information about each central figure-Chapurin, his sister igumen'ia (Abbess) Manefa, the rich widow Maria Gavrilovna, the faith-seeking Gerasimov, to name a few-is given in personal family histories inserted at crucial points. These "flashback" digressions explain why the character in question acts or-as is more often the case-reacts as he does. For example, the story of Manefa's tragic past is learned only when her seducer, Stukolov, enters the scene (part 1, chapter 13). The institution of the family, which acts as a focus in both In the Forests and On the Hills, is elemental to the Zavolzh'e byt. The little family histories behind the principal characters are not biographies but rather subplots. ${ }^{21}$

The pace of the two novels is unhurried. Short scenes follow one another, occasionally interrupted or "retarded" in epic fashion by longer descriptive passages and "flashback" histories. Moreover, to keep the pace slow and even, Melnikov de-emphasizes traditionally exceptional characters and extraordinary happenings. Criminals and crimes, for example, receive only episodic treatment.

20. See, for example, Avseenko, "Khudozhestvennoe izuchenie raskola," pp. 356, 377 ; Ezhov, "Predislovie," p. 8; A. A. Izmailov, "Bytopisatel' 'vzyskuiushchikh grada," Ezhemesiachnye literatumye $i$ popularno-nauchnve prilozheniia $k$ shurnalu 'Niva' na 1908 g., 1 (1908) : 456; Levin, "Epopeia," p. 3 ; and L. M. Lotman, "Roman iz narodnoi zhizni," Istoriia russkogo romana, 2 vols. (Moscow and Leningrad, 1962-64), 2:410. On style see Lotman, "Mel'nikov-Pecherskii," p. 223, and "Roman iz narodnoi zhizni," p. 406; D. A. Markov, "Osobennosti leksiki romana P. I. Mel'nikova-Pecherskogo $V$ lesakh" (doctoral diss., Moscow State University, 1962), pp. 22, 516, and Vinogradov, "Fol'klornye istochniki," pp. $x$-xiii.

21. For more on the subject of character histories in In the Forests and On the Hills see Iaroslavtseva, "Roman P. I. Mel'nikova," pp. 378-86, and Lotman, "Roman iz narodnoi zhizni," pp. 408-9. 
The attempt of the Krasnoiarsky counterfeiters Stukolov and igumen (Abbot) Mikhail to lay their hands on Chapurin's wealth and the efforts of the lecherous Khlyst holy man Denisov to seduce Dunia Smolokurov, along with many other, more commonplace occurrences, merely "flare up" only to die out quickly and give way to new, usually unrelated episodes, histories, or descriptions. ${ }^{22}$

Perceived as a "broad folk épopée," In the Forests and On the Hills have two discernible structural principles-one stylistic, the other compositional. The first is the pervading oral nature of both works. Characters, settings, and events are not described or sketched so much as talked about. Significantly, each installment of the novels appeared in Russkii vestnik with the subtitle "Rasskaz" ("A Tale"). ${ }^{23}$ The narrative technique again is skaz, and the narrator is one "assimilated" to the Zavolzh'e byt. The material thus acquires a synthetic stylistic quality. The effect is that of a mosaic, of bits and pieces of narrative fitted together to form a unified whole. Compositionally, the novels are open-ended. Paramount in the two works is the everyday flow of life in the Trans-Volga area which is conveyed by a series of small novellas about persons, places, and things. They follow one another in the loosely organized, formless manner of a chronicle. Even the more memorable happenings-such as Nastia's funeral, the important decision-making conference of Old Believer monastic leaders, the Khlyst raden'e or ritual celebration-are woven so carefully into the narrative that the reader is led to believe that he is working his way through a rambling account rather than a richly variegated novel-dilogy.

To designate In the Forests and $O n$ the Hills as either epics or artistic chronicles, however, is to overlook two very important aspects of these works -plot and message. There is nothing unanticipated, inconsistent, or "wrong" about the plausible though unexciting way the lives of the Chapurins and the Smolokurovs work themselves out, nothing particularly tendentious about the broad truths or "prophecies" in either work-if the two novels are regarded as romances. As the American critic Richard Chase has incisively observed, romance typically conveys broad moral truths. ${ }^{24}$ In the course of these two novels, several broad moral truths are indeed articulated. One is that the forces of good and evil affect everyone's actions and behavior. Another is that man suffers reversals, even tragedies, from the devilish onslaughts of nature and society. Man endures and resists by clinging tenaciously to traditional human institutions-in the novels, the family, a system of ethics, a type of religious

22. Lotman examines this aspect of Melnikov's novels in some detail. See her "Roman iz narodnoi zhizni," p. 410.

23. It is also significant that Melnikov subtitled the separate 1875 edition of In the Forests "Told by Andrei Pecherskii" ("Rasskazano Andreem Pecherskim").

24. Richard Chase, The American Novel and Its Tradition (Garden City, N.Y., 1957), p. ix. 
faith-which offer him protection. The stories of Chapurin and his family, Smolokurov and his daughter, and the various aspects of sectarian life act as vehicles or metaphors for these truths. Chapurin is no wiser at the end of On the Hills; he is simply older and more wistful. Smolokurov is dead, his wealth repudiated by his Dunia. The Old Believer skity are officially closed, but Manefa and the other Schismatic leaders have adapted by going underground. By emphasizing byt, the lives of everyday Zavolzh'e people, by myth and by religion, Melnikov reaffirms age-old ideas about men in nature and society. The novels' protagonists cannot be shaken by elemental, cosmogonical forces. They are "flat" rather than cognitive creatures in whose existence a joie de vivre and tragedy coexist. They accept life; their individual roles are set ones. Those who deviate, notably Aleksei Lokhmatov and Smolokurov, deviate unwittingly and vainly.

Truths such as these are no more appropriate to so-called realistic fiction than are the happy or at least believable, rational, "satisfactory," though unexciting dénouements characteristic of these novels. The conversion of the Zavolzh'e skity to Orthodoxy, Chapurin's pleasure at the marriage of his lethargic daughter Parasha to frivolous Vasilii Borisych, the imaginative Flenushka's readiness to take monastic vows, Dunia's blissful union with Samokvasov, and the much-praised probity of young Vedeneev and Merkulov annoy most critics. Yet, in the romance, "solutions" such as these are usual. Romance, as Leslie Fiedler points out, is programmed literary entertainment with a logical and gratifying outcome-the villains receive their due and the virtuous are justly rewarded. ${ }^{25}$

In the final analysis, therefore, the question whether In the Forests and On the Hills are separate, unequal, yet related works is secondary. The problem of how to approach and understand the two novels is of foremost importance. As indicated here, to call In the Forests and On the Hills "epic" is to ignore important ideological and compositional aspects traditionally regarded as "shortcomings," but to apply the term romance to the two long novels provides one with a basis for interpreting the works both more perceptively and more completely.

Harry Levin writes, "The romance-from verse to prose, from manuscript to print-was a transitional form, standing somewhere between the idealism of the epic and the realism of the novel."26 To understand adequately those

25. Leslie Fiedler, Love and Death in the American Novel (New York, 1966), pp. 135, 139-40. The same observation is also made by Railo, Haunted Castle, pp. 57, 63, 66, 69-72, 326-27.

26. Harry Levin, The Gates of Horn: A Study of Five French Realists (New York, 1963), p. 40. 
giant books, In the Forests and On the Hills, one must first determine the type of fiction Melnikov preferred and its direction from the lesser-known, shorter works which preceded them. In other words, the characteristic traits discernible in his early fiction constitute a prolegomenon to any interpretation of these later novels. A brief examination of this writer's early travel story, short provincial sketches, and two remarkable novellas, as well as the famous novels, makes it clear that Melnikov is fundamentally a nonrealist, a writer whose oeuvre is characterized by highly stylized narratives, out-of-the-ordinary settings and peoples, and "primitive" prose forms. Returning to Levin's definition, it is fitting to call Melnikov a romancer, since his most outstanding fiction, the early story The Krasilnikovs, two novellas, and novels, are romancesworks written in a transitional form with neither the idealism of the epic nor the novel's intense realism, but rather with elements of both. The designation given him by the Formalist critic Boris Eikhenbaum is thus apt: Melnikov belongs to a "minor line" (mladshaia liniia) of nineteenth-century Russian prose writers. He is a member of a literary school "crushed and forgotten in Russian prose in an age of Dostoevsky and Tolstoy," a prose-writing maverick active during the heyday of Realistic writing. ${ }^{27}$

27. B. M. Eikhenbaum, "O proze Kuz'mina," Skvoz' literaturu (Leningrad, 1924), pp. 196-97. 